Маслова-Лисичкіна Ірина Анатоліївна, аспірантка,

Київський національний університет культури імистецтв

\title{
МАСОВЕ СВЯТО ЯК ЗАСІБ ВИХОВАННЯ ЛЮДИНИ В РАДЯНСЬКУ ДОБУ
}

У статті досліджуються особливості системи масових свят, яку впроваджувала радянська влада в Києві з метою політико-виховної роботи 3 населенням та формування колективного свята ідеологічного характеру. Таким чином, на перший план виходили державні, загальнополітичні свята, які утверджували комуністичні ідеали і цінності, трудові та револючійні традиції, щзо призводило до нівелювання етнічної основи українських свят.

Ключові слова: свято, обряд, традиція, радянська обрядова система, радянські масові свята.

В статье исследуются особенности системы массовых праздников, которую внедряла советская власть в Киеве с иелью политико-воспитательной работь с населением и формирования коллективного праздника идеологического характера. Таким образом, на первый план выходили государственные, общеполитические праздники, которые утверждали коммунистические идеалы и ценности, трудовые и револючионные традиции, что приводило к нивелированию этнической основь украинских праздников.

Ключевые слова: праздник, обряд, традищия, советская обрядовая система, советские массовые праздники.

The article examines the peculiarities of the system of mass holidays which was applied by the Soviet authorities in Kiev with the aim of political and educational work with the population and the formation of a collective celebration of an ideological nature. So, on the first plan out of the state, political holidays that illustrated the Communist ideals and values, labour and revolutionary traditions that led to the leveling of the ethnic basis of Ukrainian holidays.

Key words: celebration, ceremony, tradition, the Soviet mass celebration, the Soviet ceremonial system.

Протягом десятиліть радянська влада намагалася впроваджувати нові свята та обряди, змінити значення старих традицій, щоб викоренити етнічну культуру українців, національні цінності, сформовані протягом тисячоліть, з метою побудувати зовсім нове соціальне суспільство, у якому культивувався образ СРСР як демократичної держави нового такту.

Система обрядів, яку впроваджувала радянська влада в Києві, була однією 3 результативних форм політико-виховної роботи з населенням. Термінологія («радянська культура», «обрядовість»), яка відображала в собі радянський тоталітарний режим, 
взагалі заперечувала навіть саму можливість існування релігійних вірувань та обрядів, які не відповідали соціалістичному способові життя. Це, у свою чергу, призвело до певної руйнації національної свідомості, історичної пам'яті, духовності українського народу.

Метою дослідження є аналіз процесів і методів впровадження радянської системи масових свят в умовах Києва.

Такі автори як Д. Генкин, Н. Лобачева, М. Устинова, В. Борисенко, О. Стешенко, О. Курочкін, В. Зінич, Д. Угринович та ін. намагалися розкрити поняття масового свята радянського періоду, а також піднімали проблеми розвитку українських свят у зазначений період.

Незважаючи на наявність певного наукового доробку з цієї проблематики, можна твердити, що питання радянізації масових свят і відновлення національної етнічної обрядової пам'яті є актуальним i, на жаль, недостатньо висвітленим у вітчизняній культурології та мистецтвознавстві.

У Києві, як і в цілому в УРСР, протягом десятиліть формувалася досить розгалужена система радянських свят і обрядів: дитячих, молодіжних, побутових, трудових, революційних, державних. Традиції, які сповідувала радянська влада, були спрямовані, з одного боку, на викорінення релігійного, родинно-обрядового циклу обрядів, а з іншого - на формування колективного свята ідеологічного характеру. Так, на перший план виходили державні, загальнополітичні свята, які ілюстрували комуністичні ідеали і цінності, трудові та революційні традиції радянського народу [14].

Усі процеси, які мали на меті створення нової системи обрядів і видалення 3 етнічної культури українців релігійних і сімейних свят, поступово формували колективну свідомість, а також створювали необхідні умови для того, щоб спільні цінності значно переважали над особистими, родинними зв'язками. Ідеальним результатом розвитку вказаних процесів було досягнення будь-яким радянським святом всезагального відчуття прагнення до єдиної мети [2]. На думку вчених Н. Лобачевої, М. Устинової, у процесі становлення соціалістичних цінностей, відносин і культури в цілому кожний обряд чи свято повинні виконувати, перш за все, виховну функцію. Тільки після цього мова буде йти про емоційне сприйняття населенням запропонованих обрядів [9]. Тому слід зазначити, що всі ці нововведення, в першу чергу, були покликані виконувати ідеологічно-виховну функцію, формуючи суспільні настрої та впливаючи на свідомість,а при цьому не враховували думку широких верств населення.

Важливо відзначити головні фактори, за якими ідентифікували радянські традиції. Так, радянським, а отже, допустимим, вважався обряд, структура та зміст якого були радянськими, а елементи народної традиційної обрядовості використовувалися лише для підсилення емоційного сприйняття. Окрім цього, обряд мав будуватися на основі вироблених партією визначень радянської культури, тобто обряд або свято мало бути інтернаціональним - однаково рідним для представників усіх народів. Відповідно ті свята, що не містили в собі вищевказаних ознак існувати не могли [13].

Формування суто радянської системи традицій було необхідним для того, щоб відбулося закріплення образу СРСР як єдиної та могутньої держави. Для цього були створені загальнорадянські символи й атрибути: Герб і Прапор СРСР, Гімн Радянського 
Союзу, скульптури та портрети В. Леніна, К. Маркса, Ф. Енгельса тощо. Використання цих атрибутів було обов'язковим для проведення кожного радянського свята, які впроваджувалися в повсякденне життя з другої половини XX ст. Були випадки, коли інструкції з проведення свят доходили до абсурду і позбавляли місцевих культурних працівників ініціативи та самостійності. Так, у рекомендації до урочистого вручення молоді паспорта громадянина СРСР зазначалося про обов'язкове використання радянської символіки: державного прапора СРСР та Української республіки, герба республіки. «Стіл на сцені бажано вкрити скатеркою червоного, синього чи зеленого кольору. Вода, квіти чи інші аксесуари на столі недоцільні, хоча взагалі інтер'єр повинен бути прикрашений живими квітами» [15]. Але, для того, щоб обряд мав не тільки революційне забарвлення, а й національне, використання елементів української символіки в деяких випадках віталося. Так, при проведенні свят було дозволено використовувати національні мелодії та пісні українських композиторів, але сам обряд мав вміщати в собі головні інтернаціональні риси. Дуже часто масові свята та обряди в Україні озвучувалися російською мовою. Таким чином, здійснювалася «інтеграції російської культури» в іноетнічне середовище [9].

Характерним був пошук радянським керівництвом методів і способів, які б пришвидшили втілення в життя нової радянської обрядовості. Одним із таких способів було наділення радянської обрядовості частиною елементів, характерних для української традиційної культури. Прикладом цього може служити використання перероблених колядок і щедрівок. На відміну від традиційних, головну роль у нових щедрівках відігравали теми комуністичної партії, Леніна.

Подібне відбувалося з багатьма народними святами, які начебто очищалися «від шкідливих ідеологічних, зокрема релігійних, нашарувань» [11]. Так, свято Івана Купала могло відкриватися урочистим підняттям прапора із зображенням голуба.

Формування та становлення радянської культури та свят зокрема проходило під пильним контролем культармійців, працівників ідеологічних закладів. На цьому етапі бібліотеки та клуби виконували провідні функції у процесі формування радянської свідомості. Ці заклади, окрім вирішення питань дозвілля, свят та урочистостей, виконували роль пропагандисько-ідеологічних закладів і відігравали одну з важливих функцій духовного формування молоді. Для здійснення ефективної пропаганди нової системи свят та обрядів партійне керівництво розробило цілий ряд заходів, які цілеспрямовано впроваджувалися в життя киян. Для того, щоб полегшити роботу культпрацівникам, видавалися великими тиражами різноманітні книги, брошури, сценарії та методичні посібники. Окрім того, проводилися методичні семінари, організовувалися з'їзди завідувачів клубів, викладачів, бібліотекарів. На таких з'їздах зазвичай розглядалися способи та методи проведення тісї чи іншої події. Метою проведення цих заходів було ознайомлення працівників, які були причетні до впровадження в життя населення радянської системи обрядів, з теоретичними питаннями обрядознавства і закріплення практичних рекомендацій до повсюдного втілення в побут рекомендованих Комісією нових громадянських свят, навчити кадри відповідно до інструкції їх правильно проводити та організовувати [15]. У бібліотеках проводилися літературні вечори, читацькі конференції, огляди книг тощо. У клубах - наочні агітації, 
бесіди, лекції, тематичні вечори. Не дивлячись на те, заробітна плата культпрацівників була малою, дана посада давала можливість отримати певні пільги, зокрема житло відповідно до постанови Ради Міністрів Української РСР, а Київський технікум підготовки культосвітніх працівників давав можливість отримати освіту молоді [3].

Важливою прикметою радянського способу життя була організація демонстрацій, святкових мітингів, змістом яких було схвалення політики, яку проводила тодішня влада. На сторінках періодичних видань прописувалися заклики до прискорення економічного розвитку, до боротьби з «буржуазною» ідеологією, що стоїть на заваді загального радянського «світлого майбутнього». У таких закладах як палаци культури, кінотеатри, школи, ленінські кімнати тощо проводилися кінофестивалі, читацькі конференції, тематичні виставки, які пропагували ленінські ідеї, політику КПРС [5]. Ідеологічна пропаганда була всеохоплюючою.

Радянізація святково-обрядової системи була покликана сприяти ідеологічному забезпеченню господарських планів. У 1964 р. в Москві на Всесоюзній нараді-семінарі, за ініціативою ЦК КПРС було вперше поставлене питання про централізоване створення і втілення в життя радянської обрядової системи. Рішення цієї наради було таким: вивчати, вдосконалювати й популяризувати радянські свята та обряди. Важливість прийняття цього рішення підтверджував той факт, що робота 3 цих питань була поставлена на державну, цілеспрямовано керовану основу.

Підтвердженням серйозності намірів радянського керівництва було створення в 1964 р. при Міністерстві культури Української РСР республіканської художньої ради 3 вивчення і впровадження радянських свят і обрядів. Далі, в 1969 р. іiі було перетворено у Комісію з радянських традицій, свят і обрядів при Раді Міністрів УРСР. Таке перетворення було здійснено задля об’єднання зусиль всіх міністерств, відомств, різноманітних спілок і результативної дієвості [1]. Створена комісія, у відповідності 3 рішеннями ЦК Компартії Президіуму Верховної Ради і Ради Міністрів УРСР, вивчала, розробляла та впроваджувала нові радянські обряди та свята, крім цього вона займалася координуванням діяльності міністерств, відомств, обласних рад депутатів трудящих і їх обрядових комісій, творчих союзів та інших наукових і суспільних організацій республіки з розвитку радянської обрядності як важливого засобу комуністичного виховання трудящих [15].

Зрозуміло, що ця установа була створена для того, щоб контролювати загальні процеси у святково-обрядовій сфері населення та проводячи централізовану політику, спрямовану проти самобутніх традицій українського народу. Згадана комісія спроектувала та поширила типові конкретні рекомендації-сценарії, які використовувалися як основа для відповідних церемоніалів на всій території України.

Утворивши дану Комісію та Комісії при виконавчих комітетах Рад народних депутатів, радянська влада забезпечила себе цілісною структурою, яка мала всі можливості для здійснення централізованого підвищення ідейно-морального та естетичного впливу соціалістичної обрядовості на всі вікові та соціально-професійні групи населення.

Новостворена установа, не зволікаючи, відразу розпочала виконувати свої прямі обов’ язки, тобто втілювати в життя нову радянську обрядовість, а також оспівувати 
образ радянської людини. У першу чергу, до цієї акції було залучено ЗМІ. Аналіз журналів і газет радянського періоду показав, що почали з'являтися численні рубрики,в яких було представлено процес «оновлення» радянського суспільства: «Новий час нові обряди», «Нові звичаї - нові обряди» тощо. Окрім цього, видання містили інформацію про традиційні українські свята як ілюстрацію для висвітлення процесу трансформації старих свят у «нові радянські свята» [8; 10]. Телебачення відігравало важливу роль у впровадженні нових тенденцій, особливо це було помітно в кін. 70-х рр. Зміст телепрограм містив інформацію про роботу обрядових комісій, про роль громадських організацій у вивченні та впровадженні нової обрядової системи в містах і трудових колективах [13].

Влаштовуючи масові свята, які були присвячені історично значущим подіям, таким як річниці Перемоги радянського народу у Великій Вітчизняній війні, ювілеї створення СРСР, 50-ти і 60-ти річчя Великого Жовтня чи 100-річчя з дня народження В. Леніна, радянське керівництво прагнуло демонструвати єдність партії та народу, процвітання радянського устрою тощо. Варто відзначити, що такі заходи слугували потужною рекламою, яка давала можливість зомбувати людей, а також створювала необхідні умови для здійснення контролю над всіма сферами людської діяльності. Активно пропагувалася ідея про те, що радянська людина, яка веде активний спосіб життя, виражає свою громадянську позицію, ставлення до певної події у колі друзів і в трудовому колективі, мала відчувати себе частиною великої соціальної спільноти радянського народу [2].

Прикладом доведення ефективності діяльності культпрацівників може служити той факт, що під час святкування Першого Травня велика кількість жителів Києва зібралися на демонстрації з плакатами «Хай живе комуністична партія», «Слава Леніну» тощо. Масові свята не обходилися без підведення підсумків соціалістичних змагань, промов на честь лідерів Комуністичної партії. У рамках святкування проводилися концерти, на яких також славилася Комуністична партія, Уряд, Комсомол. Свято Першого Травня за своїм змістом цілком відповідало визначенню радянського свята, як особливого багатогранного суспільного явища, яке відображало життя в цілому всього суспільства [2]. Зазначене свято є прикладом суто радянського свята, яке було покликане здійснювати ідейне об'єднання людей, насадження політичних, моральних та естетичних поглядів партійного керівництва.

У наступні роки політика радянської влади не змінила свого спрямування, тобто процес насадження власної ідеології і далі розгортався відповідно до старих принципів, видозміненими були лише методи, які застосовували при втіленні в життя поставлених цілей. Відбувалося здійснення суцільної секуляризації та переідеологізації свят.

І з сер. 60-х рр. почалася криза радянської політики в культурній сфері. У цей період, який назвали «хрущовською відлигою», неочікувано для радянського керівництва, відбувається поступове відродження українських традицій. Помітною була акумуляція традиційної культури в межах можливого, а також синтез старих і нових обрядів. Зрозуміло було, що партійне керівництво не могло чинити опір цим процесам і було змушене погоджуватися на можливість використання народної творчості, народних звичаїв і обрядів. Київський обком КПУ України у протоколі від 16 червня 1956 р. 
вказував на одноманітність ювілеїв та радянських свят [4]. Відповідно елементи української символіки, народні звичаї, традиції використовувалися з метою посилення художньо-образного, емоційного впливу комуністичної ідеології на всі верстви населення. Звичайно, що такі заходи радянської влади певним чином реанімували етнокультуру, але, водночас, використання лише певних народних елементів в обряді призводило до перекручування і сприйняття українського як меншовартісного.

Розуміючи, що стрімке відродження української культури може підірвати авторитет радянської ідеології, комуністичне керівництво пішло на нові дії. Починаючи з кін. 60-х рр., у Києві управління культури видає накази, в яких наголошувалося на здійсненні конкретних заходів щодо поліпшення атеїстичної пропаганди та впровадження нової радянської обрядовості. Відповідно до цього наказу, вже у 1967 р. в усіх районах Києва проводилися спеціальні семінари. Метою проведення цих семінарів було розкриття питання атеїстичного виховання серед населення, а також аналізувалася ефективність заходів зі впровадження радянської обрядовості [6].

Кін. 70-х - поч. 80-х рр. ХХ ст. позначився кризовими тенденціями у радянському обрядотворенні. Ознаки такої кризи проявлялися у ставленні людей до організації та проведення різноманітних ювілеїв, річниць чи державних свят. Склалася така ситуація, що навіть у брежнєвські часи, часи масового розчарування радянською ідеологією, продовжувала розгортатися пропаганда впровадження радянської обрядової системи. Так, у 1983 р. на пленумі ЦК КПРС наголошувалося на наполегливому впроваджені радянської обрядовості. Перший секретар ЦК КПУ В. Щербицький зазначав, що радянська обрядовість відображає ідеї нового суспільного устрою, нового побуту, нових відносин між людьми, а соціалістичні обряди спонукають радянську людину до соціальної активності, корисної громадської діяльності. На думку В. Щербицького, соціалістичні свята і обряди дають відповідь на ключові світоглядні питання про сенс життя, людське щастя і сприяють утвердженню науково-матеріалістичного світорозуміння [16].

Висновки. Зрозумілим є той факт, що різка заборона функціонування старих традицій, обрядів і звичаїв та заміна їх т. зв. «новими», рівнозначна «підрізуванню коріння» [16] народній ідейності, моралі, світогляду. Процеси, які мали на меті заміну традиційної культури на нову, створену для політизації суспільства, пропагування комуністичного режиму, стирання відмінностей між народами призвели до руйнації історичної пам'яті, духовності народу. Наслідком таких змін стали негативні прояви в духовному та матеріальному житті українського народу, що проявляється в нігілістичному ставленні до навколишнього середовища, в неповазі до старших, у зневірі в духовних цінностях тощо.

Таким чином, вищезазначені процеси творення соціалістичної обрядовості сприяли формуванню рис нової спільноти, яка отримала назву «радянський народ». Усі ці процеси поступово витісняли елементи етнічної культури, що, у свою чергу, призвело до руйнації національної свідомості. Особливо процес руйнації відчули на собі жителі Києва, які переживали потужний вплив радянізованого міста.

Та, не зважаючи на активну та цілеспрямовану діяльність радянського керівництва зі впровадження нової ідеології, сприйняття ії̈ населенням було неоднозначним. Люди розуміли, що не завжди те, що прославлялося звідусіль, відповідало дійсності. 
Сьогодення є яскравим доказом того, що український народ сприймав насаджувану систему обрядів не так, як описувалося в документах партійного керівництва.

\section{Jimepamypa:}

1. Борисенко В. Традииії і життєдіяльність етносу: на матеріалі святково-обрядової культури українців / Борисенко В. - Київ : Унісерв, 2000. - С. 7. 2. Генкин Д. М. Массовые праздники / Генкин Д. М. - Москва : Просвещение, 1975. - С. 53. 3. Державний архів Київської області : Ф. - P-4791. - Оп.2. - Спр. 92. - Арк. 1. 4. Державний архів Київської області: Ф. -880. - On.11. - Спр. 92. - Арк. 22 - 24. 5. Державний архів Київської області : Ф. - 880. On.12. - Спр. 2118. - Арк.483. 6. Державний архів Київської області: Ф. - 4791. - On. 2. Спр. 629. - Арк. 58 - 61. 7. Зінич В. Т. Сочіалістичні перетворення - паростки нового комуністичного в культурі та побуті робітників Радянської України / Зінич В. Т. - Київ 1963. - 76 с. 8. Зоч В. Від ілюзій до реальності / Зои В. // Соціалістична культура. - 1978. № 6. - С. 26-27. 9. Лобачева Н. П. Задачи этнографической науки в разработке, внедрении и совершенствовании сочиалистической обрядности / Н. П. Лобачева, М. Я. Устинова // Советская этнография. - 1986. -№2. - С. 24-46. 10. Орлова С. А. Современная городская культура и человек / Є. А. Орлова-М. : Наука, 1987. - 192 с. 11. Стешенко О. Добрий світ традииій / О. Стешенко // Соціалістична культура. - 1971. -№5. - С. 27. 12. Угринович Д. М. Обряды за и против / Угринович Д. М. - Москва : Политиздат, 1975. - С 176. 13. Центральний державний архів вищих органів влади та управління України: Ф. - 2, On.14. - Спр. 817. - Арк.83. 14. Центральний державний архів вищих органів влади та управління України: Ф. - 2. - Оп.14. - Спр. 819. - Арк. 6. 15. Центральний державний архів вищих органів влади та управління України: Ф. - 2, - Оп.14. - Спр. 821. - Арк.36-37. 16. Щербиикий $B . X X V$ съезд КПСС о совершенствовании социалистического образа жизни и формировании нового человека / Щербиикий В. - Москва : Политиздат, 1977. C. 217 . 